\title{
Nutrient Management for Organic Farming: A Case Study
}

\author{
Robert L. Mikkelsen*
}

\begin{abstract}
There is increasing interest from farmers and consumers in food grown without the use of synthetic pesticides and inorganic fertilizers. This case highlights the history of one farmer in the Coastal Plain of North Carolina who has grown vegetables for 12 yr using only composted turkey (Meleagris gallopavo) litter for a nutrient source. Since he began production, the concentration of several plant nutrients has increased as much as fivefold in the soil. Although there were no apparent problems with the soil, the certification board that oversees his production practices questioned this rapid change in nutrient status and the implications for the future. In presenting this case, students were shown a video recording of the farmer discussing his operations and his concerns for the future. The students were then asked to make practical management recommendations to deal with the current trends of nutrient accumulation, to determine the conditions where excessively high nutrient concentrations may become a problem, and to construct a whole-farm nutrient budget that considers the initial sources of nutrients entering the farm and their ultimate fate. A follow-up session allowed the students to discuss their ideas and critique each other using the available information.
\end{abstract}

$\mathrm{T}$ HE production of organically grown crops has been expanding in recent years. Many consumers are willing to pay a premium for food products that are grown without the use of synthetic pesticides and inorganic fertilizers. This case highlights the nutrient management concerns of an individual vegetable grower who uses organic materials and composts as his sole source of nutrients. The data for this case were gathered from 12 yr of soil analysis, historical production data, and personal interviews.

\section{THE CASE}

Stefan Hermann grew up in Germany and studied agricultural sciences at the University of Cologne. After graduation, Stefan decided that he would like to apply the theoretical knowledge he had learned in school to real-life production agriculture. As a self-proclaimed city kid, he had never lived on a farm, but was attracted to the idea of managing some land that belonged to the family in North Carolina. Stefan and his wife felt strongly that agricultural production should be selfsufficient and not rely on off-farm inputs of chemicals and nonrenewable resources for operation.

With these goals in mind, they moved to a small community in eastern North Carolina and began to implement their plan. The farm was located in Sampson County, on the Coastal Plain where the soils are predominantly Entisols that receive between 1000 and $1100 \mathrm{~mm}$ of rainfall annually (Table 1). At

Department of Soil Science, Box 7619, North Carolina State Univ., Raleigh, NC 27695-7619. Received 20 July 1998. *Corresponding author (robert mikkelsen@ncsu.edu).

Published in J. Nat. Resour. Life Sci. Educ. 29:88-92 (2000). http://www.JNRLSE.org some earlier time, the farm had been used for grain and tobacco (Nicotiana tabacum L.) production, but the land had been overgrown with brush and weeds for many years. Stefan decided early on that he would use no inorganic fertilizers or synthetic pesticides on this farm, thereby allowing his vegetables to be certified as organically grown. He remembered that his neighbors were highly skeptical of this newcomer who was trying to raise vegetables in what Stefan termed "the pest capital of the world."

Stefan found that he had easy access to a huge supply of nearby poultry litter and swine (Sus scrofa) manure (Table 2). He recalled that when he first began, most animal producers were rather careless with their waste management and viewed manure primarily as a material that required disposal. Stefan learned that turkeys in North Carolina are generally raised in large barns with a floor covering of wood shavings that serves to absorb moisture and cushion the birds while they are lying down. For turkeys, the amount of shavings used varied from 2 to $6 \mathrm{Mg} / 1000$ birds produced. The mixture of turkey manure and wood shavings, termed litter, is periodically removed from the barn and applied to surrounding cropland. He made arrangements with a local turkey grower to obtain all of the litter that he wanted. Swine manure was less attractive as a nutrient source since it is primarily flushed from the barns as a dilute liquid (effluent) and then treated in open anaerobic lagoons. For Stefan to utilize swine manure on his farm, it would have required the transportation of considerable water or the acquisition of a solid separator, neither of which was immediately practical for him.

Sampson County (245 000 ha) has an abundance of animal agriculture. More than 2 million swine, 11 million turkeys, and 5 million broiler chickens (Gallus gallus) are raised each year in this one county alone (NCAS, 1998). Surrounding counties have similar levels of livestock production. The high intensity of animal production has resulted in a regional surplus of nutrients compared with available agricultural land in this region (Barker and Zublena, 1996). Despite this regional excess of manure-derived nutrients, more than $7000 \mathrm{Mg}$ of N, $800 \mathrm{Mg}$ of $\mathrm{P}$, and $5000 \mathrm{Mg}$ of $\mathrm{K}$ as inorganic fertilizer are sold annually in this county alone (NCDA, 1997). There was considerable pressure on livestock producers by state regulators to utilize the manure-derived nutrients in an acceptable and environmentally sensitive way and to follow strict nutrient management plans.

Stefan composted the fresh turkey litter in open windrows before application to his fields (Table 3). The litter was periodically turned with a tractor and aged for approximately $1 \mathrm{yr}$ before being added to the fields. He felt that the composting process helped to stabilize the nutrients and made the $\mathrm{N}$ less vulnerable to leaching on these sandy-textured soils. During the compost process, a 20 to $30 \%$ loss of volume was anticipated.

Stefan followed a 4- to 5-yr rotation for crop production on his fields. He began the sequence with high-value crops such as tomato (Lycopersicon esculentum Mill.) and eggplant

Abbreviations: PAN, plant-available nitrogen. 
Table 1. Soil profile description of Chipley sand (Aquic Quartzipsamments) found predominantly in Mr. Hermann's fields.

\begin{tabular}{lrl}
\hline Horizon & Depth & Description \\
\hline & $\mathrm{cm}$ & \\
Ap & $0-15$ & Dark grayish brown, sand, single grained, strongly acid \\
$\mathrm{Bw}$ & $15-35$ & Yellowish brown, sand, single grained, strongly acid \\
$\mathrm{C} 1$ & $35-90$ & Pale brown, sand, few distinct mottles, very strongly acid \\
\hline
\end{tabular}

Table 2. Amount of excreta produced by livestock.

\begin{tabular}{lcccc}
\hline Type of livestock $\dagger$ & $\begin{array}{c}\text { Body } \\
\text { wt. }\end{array}$ & $\begin{array}{c}\text { Moisture } \\
\text { content }\end{array}$ & $\begin{array}{c}\text { Typical } \\
\text { volume }\end{array}$ & $\begin{array}{c}\text { Typical manure } \\
\text { wt. (wet) }\end{array}$ \\
\hline Dairy cow & $\mathrm{kg}$ & $\%$ & $\mathrm{~L} / \mathrm{d}$ & $\mathrm{kg} / \mathrm{d}$ \\
Beef cow & $450-650$ & 90 & 57 & 50 \\
Pig & $200-450$ & 90 & 27 & 20 \\
Sheep & $45-75$ & 90 & 4 & 5 \\
1000 laying hens & $25-45$ & 89 & 4 & 1 \\
1000 broilers + litter & 2000 & 70 & 115 & 130 \\
1000 turkeys + litter & 5000 & 30 & 36 & 19 \\
\hline
\end{tabular}

$\dagger$ Cow, Bos taurus; pig, Sus scrofa; sheep, Ovis aries; chicken, Gallus gallus; turkey, Meleagris gallopavo.

Table 3. Typical chemical composition of fresh and composted turkey litter used as a nutrient source by Mr. Hermann and swine waste in anaerobic swine lagoons.

\begin{tabular}{|c|c|c|c|c|c|c|c|c|c|c|c|}
\hline Type $\dagger$ & $\mathrm{pH}$ & Total N & $\mathrm{P}$ & $\mathrm{K}$ & $\mathrm{Ca}$ & $\mathrm{Mg}$ & $\mathrm{S}$ & $\mathrm{Fe}$ & $\mathrm{Mn}$ & $\mathrm{Zn}$ & $\mathrm{Cu}$ \\
\hline & & \multicolumn{6}{|c|}{$\longrightarrow \mathrm{kg} / \mathrm{Mg}$} & \multicolumn{4}{|c|}{$-\mathrm{g} / \mathrm{Mg}$} \\
\hline $\begin{array}{c}\text { Stockpiled } \\
\text { litter* }\end{array}$ & 8.6 & 30 & 17 & 14 & 21 & 4 & 5 & 650 & 325 & 320 & 250 \\
\hline $\begin{array}{c}\text { Composted } \\
\text { litter } \$\end{array}$ & 7.8 & 221 & 18 & 16 & 30 & 6 & 6 & 1740 & 580 & 560 & 700 \\
\hline $\begin{array}{l}\text { Anaerobic } \\
\text { swine efflu }\end{array}$ & $\begin{array}{l}7.8 \\
\text { lent }\end{array}$ & 600 & 100 & 500 & 110 & 37 & 44 & 10 & 2 & 7 & 2 \\
\hline
\end{tabular}

$\dagger \mathrm{C} / \mathrm{N}$ ratio of the materials are: stockpiled litter, 25:1; composed litter, 17:1; pine shavings alone, 700:1, swine lagoon effluent, 3.5:1.

$\$$ Litter concentrations calculated on wet wt. basis with $33 \%$ moisture.

(Solanum melongena L.). Cucumber (Cucumis sativas L.) or squash (Cucurbita spp.) were next in the rotation, followed by a leafy vegetable such as lettuce (Lactuca sativa $\mathrm{L}$.). The last crops in the rotation are generally garlic or potato. A relatively heavy application of compost began the 5-yr rotation and then a lesser amount of supplemental compost was applied as needed to the following crops (the exact application rates are not known).

The use of cover crops had not fit especially well with his production schedule. Plowing cover crops into the soil before planting in the spring occasionally caused problems with achieving uniform seed germination and subsequent seedling establishment. Many vegetable crops have a small seed size and required a well-prepared seedbed to obtain good germination and the desired plant population. Additionally, to avoid problems with disease and drought, it was frequently necessary for Stefan to plant early in the spring before there was substantial growth of winter cover crops. However, Stefan always left strips of rye (Secale cereale L.), clover (Trifolium pratense L.), or vetch (Vicia monantha Retz.) in the field throughout the year as protective habitat for beneficial insects in the area. He hoped to bring additional land into production in the future and use longer rotations that would allow certain fields to be devoted to cover crop production for several years and
Table 4. Chemical analysis of soil from Stefan Hermann's farm. $\dagger$

\begin{tabular}{|c|c|c|c|c|c|c|c|c|c|}
\hline Year & $\mathrm{HM}$ & CEC & BS & $\mathrm{pH}$ & $\mathrm{P}$ & $\mathrm{K}$ & $\mathrm{Mn}$ & $\mathrm{Zn}$ & $\mathrm{Cu}$ \\
\hline \multicolumn{10}{|l|}{ Field 1} \\
\hline 1987 & 1.9 & 6.8 & 71 & 5.9 & $>400$ & 415 & 24 & 17 & 4 \\
\hline 1988 & 1.6 & 7.1 & 77 & 5.7 & $>400$ & 280 & 23 & 26 & 5 \\
\hline 1989 & 1.9 & 7.9 & 80 & 6.1 & $>400$ & 385 & 21 & 30 & 7 \\
\hline 1990 & 1.5 & 7.8 & 84 & 6.3 & $>400$ & 360 & 20 & 29 & \\
\hline 1991 & 1.3 & 7.8 & 90 & 6.6 & $>400$ & 345 & 23 & 23 & 7 \\
\hline 1992 & 1.3 & 8.4 & 86 & 6.3 & $>400$ & 475 & 12 & 29 & 9 \\
\hline 1993 & 1.3 & 7.5 & 79 & 6.0 & $>400$ & 615 & 23 & 23 & 9 \\
\hline 1994 & 1.1 & 8.3 & 86 & 6.1 & $>400$ & 625 & 34 & 60 & 23 \\
\hline 1995 & 2.5 & 9.8 & 88 & 6.0 & $>400$ & 565 & 30 & 51 & 19 \\
\hline 1996 & 2.1 & 10.8 & 84 & 5.9 & 2040 & 655 & 33 & 52 & 23 \\
\hline 1997 & 1.8 & 9.2 & 81 & 5.8 & 1675 & 455 & 29 & 44 & 15 \\
\hline 1998 & 1.7 & 9.0 & 83 & 5.9 & 1740 & 510 & 31 & 47 & 17 \\
\hline \multicolumn{5}{|c|}{$\begin{array}{l}\text { No crop response when nutrient } \\
\text { concentration is in excess of }\end{array}$} & 120 & 195 & 16 & 4 & 2 \\
\hline \multicolumn{10}{|l|}{ Field 2} \\
\hline 1990 & 1.3 & 4.2 & 14 & 4.5 & $>400$ & 47 & 20 & 3 & 1 \\
\hline 1991 & 1.1 & 5.2 & 55 & 5.1 & $>400$ & 116 & 22 & 11 & 5 \\
\hline 1992 & 0.9 & 6.4 & 75 & 5.5 & $>400$ & 203 & 15 & 19 & 8 \\
\hline 1993 & 0.8 & 6.9 & 77 & 6.0 & $>400$ & 275 & 24 & 29 & 13 \\
\hline 1994 & 0.8 & 7.0 & 77 & 5.8 & $>400$ & 265 & 25 & 45 & 17 \\
\hline 1995 & 1.1 & 8.7 & 86 & 6.0 & $>400$ & 405 & 33 & 56 & 22 \\
\hline 1996 & 0.8 & 12.4 & 92 & 6.2 & 2285 & 473 & 43 & 78 & 30 \\
\hline 1997 & 0.9 & 10.3 & 89 & 6.2 & 1970 & 240 & 32 & 62 & 23 \\
\hline 1998 & 1.0 & 10.1 & 83 & 6.0 & 1995 & 251 & 34 & 66 & 24 \\
\hline \multicolumn{5}{|c|}{$\begin{array}{l}\text { No crop response when nutrient } \\
\text { concentration is in excess of }\end{array}$} & 120 & 195 & 16 & 4 & 2 \\
\hline
\end{tabular}

$\dagger \mathrm{HM}$ is a measure of chemically reactive humic matter in the soil. BS is the proportion of the cation exchange sites that are occupied by $\mathrm{Ca}, \mathrm{Mg}$, and $\mathrm{K}$. Soil nutrients extracted with Mehlich-3 solution. Nutrient recommendations from Tucker et al., 1996.

perhaps provide some additional income from organically produced hay harvested from these fields.

Stefan first began selling his produce from a stand at a local farmers market to get experience with consumers and their preferences. However, with the heavy time demands associated with operating a farmer's market stand, he realized that he could not successfully raise the crops himself and then sit at a retail outlet all day. He switched to selling his produce through an organic farmers' cooperative that offered on-farm pick up twice each week during the growing season and then distributed the food to grocery stores, restaurants, and organic wholesalers throughout the state. He also began a community-supported agriculture program where individuals contracted directly with him to receive a certain amount of produce each week during the growing season. The contracts (also known as subscriptions) were paid each spring and provided him with valuable financial support during the time when planting and fieldwork are just beginning.

Insects were a major challenge when Stefan began his operation and he recalled losing entire crops to insect damage. Since then, he had learned to stagger planting dates, avoid pest-sensitive crops, and carefully scout fields to minimize insect damage. He had observed that insect damage decreased steadily through the years, which he attributed to an increased population of beneficial insects. When necessary, predatory insects and organically certified pest control materials were used in the fields. Weeds were another major challenge to successful vegetable production for Stefan. Cultivation and hand hoeing had been the primary methods of weed control.

Stefan had been careful to take soil samples from his primary production fields each year (Table 4). He tried to follow 
Table 5. Relative tolerance of selected horticultural crops to high concentrations of $\mathrm{Cu}$ (adapted from Jones, 1998).

\begin{tabular}{|c|c|c|}
\hline Very sensitive & Moderately sensitive & Insensitive \\
\hline $\begin{array}{l}\text { Asparagus (Asparagus } \\
\text { officinalis L.) }\end{array}$ & Apple (Malus sylestris Mill.) & $\begin{array}{l}\text { Carrot (Daucus } \\
\text { carota } \mathrm{L} .)\end{array}$ \\
\hline Bean (Phaseolus vulgaris L.) & $\begin{array}{l}\text { Broccoli [Brassica oleracea } \\
\text { (Botrytis Group)] }\end{array}$ & $\begin{array}{l}\text { Dill (Anethum } \\
\text { graveolens L.) }\end{array}$ \\
\hline Pea (Pisum sativum L.) & $\begin{array}{l}\text { Cabbage [Brassica oleracea } \\
\text { (Capitata Group)] }\end{array}$ & $\begin{array}{l}\text { Lettuce (Lactuca } \\
\text { sativa L.) }\end{array}$ \\
\hline Peanut (Arachis hypogaea L.) & Celery (Daucus carota L.) & $\begin{array}{l}\text { Onion (Allium } \\
\text { cepa } \mathrm{L} .)\end{array}$ \\
\hline $\begin{array}{l}\text { Soybean [Glycine } \max (\mathrm{L} .) \\
\text { Merr.] }\end{array}$ & $\begin{array}{l}\text { Cucumber (Cucumis } \\
\text { sativus L.) }\end{array}$ & $\begin{array}{l}\text { Spinach (Spinacia } \\
\text { oleracea L.) }\end{array}$ \\
\hline Potato (Solanum tuberosum L.) & Radish (Raphanus sativus L.) & $\begin{array}{l}\text { Beet (Beta } \\
\quad \text { vulgaris L.) }\end{array}$ \\
\hline Mint (Mentha spp.) & $\begin{array}{l}\text { Strawberry (Fragaria X } \\
\quad \text { ananassa Duch.) } \\
\text { Swiss chard (Beta vulgaris L.) } \\
\text { Tomato (Lycopersicon } \\
\quad \text { esculentum Mill.) }\end{array}$ & \\
\hline
\end{tabular}

the nutrient recommendations provided by the soil testing laboratory operated by the North Carolina Department of Agriculture as much as possible. He became concerned when a steady increase in the concentrations of certain elements was noted. He recognized that although these nutrients were essential for plant growth, they could eventually accumulate in soil to concentrations that could become problematic. As a grower of organic produce, the health of the soil was an especially important concern for Stefan and for his customers. An increase in the concentration of extractable $\mathrm{P}$ was not apparent until 1995 when the state soil testing laboratory began reporting actual soil P concentrations. Before 1995, the laboratory reported only that the $\mathrm{P}$ concentrations were not limiting to plant growth $(>400 \mathrm{~kg} \mathrm{P} / \mathrm{ha})$. After this time, they began to report actual $\mathrm{P}$ concentrations, although it was in excess of agronomic needs.

Stefan discovered that essential elements are routinely added to animal feed for the normal functioning of biochemical processes and to accelerate animal growth. However, there were few, if any, restrictions regarding the concentration of minerals in the animal waste since most land application plans are based solely on the $\mathrm{N}$ concentration of the waste. While some of the metals and nutrients are naturally occurring in the basic feed grain components \{primarily corn (Zea mays L.) and soybean [Glycine $\max (\mathrm{L}$.) Merr.]\}, the elevated concentrations are generally due to mineral supplements added to feed. For example, the recommended concentrations of trace minerals for turkey feed ranges from 40 to $70 \mathrm{mg} \mathrm{Zn} / \mathrm{kg}$ and 4 to $8 \mathrm{mg} \mathrm{Cu} / \mathrm{kg}$ (NRC, 1994). Zinc is commonly added to poultry feed as $\mathrm{ZnSO}_{4}$ or $\mathrm{ZnO}$, although $\mathrm{ZnO}$ is only half as effective at supplying bioavailable $\mathrm{Zn}$ to poultry (Wedekind and Baker, 1990). Copper is typically added to feed as either $\mathrm{CuSO}_{4}$ or $\mathrm{CuO}$; however, the bioavailability of $\mathrm{CuO}$ has been reported to be very low (Ledoux et al., 1991). Although low concentrations of $\mathrm{Cu}$ are required for proper nutrition, $\mathrm{Cu}$ is usually fed commercially at much higher pharmacological levels (100-300 mg/kg) because of its growth-promoting properties (Fisher, 1973). Underwood (1981) reported that mineral supplements in animal feed frequently contain an unnecessarily wide margin of safety to ensure against deficiency; these additions in excess of animal need may be economically wasteful and potentially harmful.
The high concentration of $\mathrm{P}$ in animal feeds has received attention due to potential environmental concerns related to manure application. For example, in the Netherlands, manure application rates are limited by the amount of $\mathrm{P}$ added to the land and the quantity of $\mathrm{P}$ removed in the harvested portion of the crop. The majority of $\mathrm{P}$ in cereal grains is in the form of phytate (also known as phytic acid or as inositol), which is largely indigestible by monoruminant animals (such as poultry, swine, and humans [Homo sapiens]). Phytatebound P must be enzymatically hydrolyzed before becoming available for animal nutrition. As a consequence of the presence of nonnutritional P, supplemental inorganic sources, such as deflourinated rock $\mathrm{P}$, dicalcium phosphate, or bonemeal, are routinely added to feed. Between 70 and $90 \%$ of the added $\mathrm{P}$ is typically excreted in the manure (Mikkelsen, 1996).

Stefan underwent a recertification process every $5 \mathrm{yr}$ to verify that his farm and his operations meet the criteria set by the Carolina Farm Stewardship Association, the regional organic certification agency. Because of potential impacts on soil health, he was concerned about the consequences of the continued accumulation of nutrients in the soil (Table 5). He was warned that if the current trends continue, he might ultimately lose his certification. However, there were very few alternative organic nutrient sources located in his area and no organic animal producers in the proximity. After many years of hard work, Stefan finally had the farm in the condition and at level of production he wanted, and he felt that an ecological balance had been established. He was uncertain about how to keep the nutrient concentrations from further escalation and to avoid potential problems, while maintaining current yields.

\section{TEACHING NOTE}

\section{Case Objectives}

This case should be used to teach students about concepts such as soil fertility, cropping practices, waste management, soil chemistry, soil health, and concepts related to nutrient cycling on a large regional scale. Students should use the case to learn about complex production and philosophical issues that may appear to conflict. It appears that the current intensive practices cannot be sustained indefinitely without excessive nutrient accumulation and potential degradation of the soil resource. However, the magnitude of the problem is not easily defined and many alternative solutions may be proposed.

When the students have completed an analysis of the case, they should be able to:

1. Synthesize multidisciplinary information from a variety of sources regarding nutrient management and use within an organic vegetable production system.

2. Be able to understand the potential environmental concerns associated with excessive accumulation of nutrients in soil and potential management options.

3. Understand the original and intermediary sources of nutrients entering a farm that uses strictly organic materials in production and the eventual fate of these nutrients.

4. Appreciate the interdependence of agroecological systems within a region (e.g., how animal feed formulations impact organic vegetable production). 


\section{Use of the Case}

\section{Stimulant Questions}

1. Is it possible to achieve a balance between nutrient inputs and harvested material on an individual farm or within a geographic region? Would this balance be easier to accomplish with organic nutrient sources or inorganic fertilizers?

2. What potential threat does accumulation of nutrients pose to the environment? How can Stefan minimize the problems associated with this accumulation while continuing to produce high-quality vegetables in a profitable way?

3. What nutrient sources do you feel should be classified as organic? What value is placed on organically grown vegetables?

4. What role should the Organic Certification groups and government agencies have in maintaining soil quality on farms?

5. What responsibilities should the turkey producers assume in the utilization of the litter? What responsibilities should the consumers of Stefan's vegetables assume in this situation?

\section{Author's Analysis and Interpretation}

This case illustrates the difficulty associated with managing organic nutrient sources on a long-term basis on any farm. The ratio and quantity of nutrients present in organic materials is rarely in balance with the plant requirement and the amount removed in the harvested portion of the plant. This accumulation of nutrients has been noted in most regions where long-term applications of animal manures, composts, or biosolids are made. Several states have attempted to regulate the accumulation of P (e.g., Deleware, Maryland, Virginia) or $\mathrm{Cu}$ and $\mathrm{Zn}$ (e.g., North Carolina) for environmental purposes, largely resulting from long-term use of organic nutrient sources.

The $\mathrm{N}$ in the turkey litter largely derives from the protein present in the feed grains. The majority of animal feed used in North Carolina is imported from out of state. The importation of nutrients from a large area of the country and the eventual concentration in a relatively small area (e.g., Sampson County) presents serious long-term challenges. The principles of nutrient movement and transport should be applied to the student's local condition to make the concept more meaningful.

The nutrient removal in the harvested portions of most plants cannot equal the accumulation that occurs when manure or compost is added at a rate to supply sufficient N. After the students examine the quantity of nutrients added to the soil during production and the amount ultimately removed, the imbalance will become apparent. For example, assuming plantavailable $\mathrm{N}$ (PAN) of 30\%, approximately $17 \mathrm{Mg}$ of compost would be required to supply $150 \mathrm{~kg} \mathrm{~N} /$ ha to a tomato crop. In this $17 \mathrm{Mg}$ compost application, approximately $290 \mathrm{~kg} \mathrm{P}$ also will be applied. In the harvested portion of the fruit (assuming $30000 \mathrm{~kg}$ fruit/ha), only 5 to $10 \mathrm{~kg} \mathrm{P} /$ ha will be removed. Compost application rates in subsequent years may be less, as a portion of the residual $\mathrm{N}$ becomes plant available. Similar calculations can be made for other potential crops and nutrients.

This soil could remain in production for many years without further $\mathrm{P}$ fertilization due to the high residual nutrient levels. Excessive P accumulation is generally not a concern for crop production; however, there are serious environmental issues that may result from this practice. Loss of $\mathrm{P}$ from soils occurs primarily via runoff and erosion. When concentrations of $\mathrm{P}$ become elevated in surface water, the ecological system is disrupted with a degradation of water quality. Phosphorus management options to reduce losses that are appropriate for Stefan and for the student's local conditions should be discussed.

The students have the opportunity to consider the source of the nutrients entering the vegetable farm in the turkey litter. Mr. Hermann is adamant about using only organic nutrient sources for his vegetable production. However, when the students consider that the $\mathrm{P}$ added to the turkey feed is identical to fertilizer (e.g., dicalcium phosphate) and passes through the bird largely unchanged and undigested, they can discuss the basis for calling it organic P. Similarly, the $\mathrm{Zn}$ and $\mathrm{Cu}$ are added as inorganic salts that pass through the bird into the manure. The decision to label one nutrient source as organic and another as inorganic is not always simple.

The practice of adding excessively high amounts of mineral supplement to animal feed is a major concern for waste management. Although there appears to be only limited justification for the high degree of supplementation, the practice continues to be standard for much of the animal feed industry. The adoption of more modern feed technology could easily allow the concentration of metals to be reduced and P excretion to be substantially minimized. Improved $\mathrm{P}$ utilization could be accomplished through addition of phytase enzyme to improve feed $\mathrm{P}$ digestibility or the use of low-phytic acid corn, which contains less indigestible $\mathrm{P}$.

The chemistry of $\mathrm{Cu}$ and $\mathrm{Zn}$ in soils should be reviewed, with an emphasis on forms in soil, phytoavailability, and potential corrective measures for toxic concentrations. The concepts of risk assessment can also be introduced at this time with potential pathways of exposure. The pharmacological benefits derived from high concentrations of $\mathrm{Cu}$ can be used as a discussion point regarding the routine addition of antibiotics to poultry feed and the rise of antibiotic-resistant bacteria (Levy, 1998).

The importance of soil $\mathrm{pH}$ needs to be stressed in the management of these metals. Copper and $\mathrm{Zn}$ both become increasing insoluble and unavailable for plant uptake as the soil $\mathrm{pH}$ increases from the acid range. These same issues of metal availability are dealt with in management plans where municipal biosolids are applied to land. The students should discuss the long-term implications of high $\mathrm{Cu}$ and $\mathrm{Zn}$. For example, can the landowner guarantee that the proper $\mathrm{pH}$ will always be maintained or that metal-sensitive crops will never be grown on these fields? Crop tolerance to high concentrations of these metals will vary among species. For example, peanut (Arachis hypogaea L.) plants are commonly grown in this region and have a low tolerance to high metal concentrations, while bermudagrass [Cynodon dactylon (L.) Pers.] has a high tolerance to these conditions.

The ethical issues involved with appropriate soil sampling can also be addressed with this case. When the possibility of regulatory action exists based on soil analysis, a landowner may be inclined to sample the portions of the field that will provide the desired results. For example, the nutrient concentrations in both Field 1 and Field 2 declined between the 1996 sampling and the 1997 sampling. This apparent anom- 
aly is explained by the fact that the fields were plowed 2 to 3 $\mathrm{cm}$ deeper than in previous years. This resulted in dilution of the nutrient concentration in the plow layer without reducing the total quantity of nutrients present. How can a regulator determine the true nutrient concentration in a field when a grower may be inclined to conceal these results?

The students will benefit from a discussion about the organic certification process. What does a consumer expect from organically grown food? What is the role of organically grown food in the global marketplace? These issues can be discussed and referenced using the USDA National Organic Program Web site (http://www.ams.usda.gov:80/nop/).

\section{REFERENCES}

Barker, J.C., and J.P. Zublena. 1996. Livestock manure nutrient assessment. p. 17-27. In M.B. Coelho and E.T. Kornegay (ed.) Phytase in animal nutrition and waste management. BASF, Mt. Olive, NJ.

Fisher, C. 1973. Use of copper sulfate as a growth promoter for broilers. Feedstuffs 45 (16 July) p. 24-25.
Jones, J.B., Jr. 1998. Plant nutrition manual. CRC Press, Boca Raton, FL. Ledoux, D.R., P.R. Henry, C.B. Ammerman, P.V. Rao, and R.D. Miles. 1991. Estimation of the relative bioavailability of inorganic copper sources for chicks using tissue uptake of copper. J. Anim. Sci. 69:215-212.

Levy, S.B. 1998. The challenge of antibiotic resistance. Sci. Am. 278(3):46-51

Mikkelsen, R.L. 1996. Best management practices for plant nutrients. p. 29-40. In M.B. Coelho and E.T. Kornegay (ed.) Phytase in animal nutrition and waste management. BASF, Mt. Olive, NJ.

National Research Council. 1994. Nutrient requirements of poultry. 9th ed. Committee on Animal Nutrition, National Academy Press, Washington, DC.

North Carolina Department of Agriculture and Consumer Services. 1997. North Carolina Fertilizer Tonnage Rep. 1995-1996. NCDA, Raleigh, NC.

North Carolina Agricultural Statistics. 1998. North Carolina Agricultural Statistics. NCDA, Raleigh, NC

Tucker, M.R., J.K. Messick, and C.C. Carter. 1996. Crop fertilization based on North Carolina soil tests. North Carolina Dep. of Agriculture. Circu. 1. NCDA, Raleigh, NC.

Underwood, E.J. 1981. The mineral nutrition of livestock. 2nd ed. Commonwealth Agricultural Bureaux, Farnham Royal, UK.

Wedekind, K.J., and D.H. Baker. 1990. Zinc bioavailability in feed-grade sources of zinc. J. Anim. Sci. 68:684-689. 